Original article

\title{
Secondary School Teachers' Opinions on the Use of Informatics Network (EBA) in Education
}

\author{
Ortaokul Öğretmenlerinin Eğitim Bilişim Ağı (EBA) Kullanımı \\ Hakkındaki Görüşleri
}

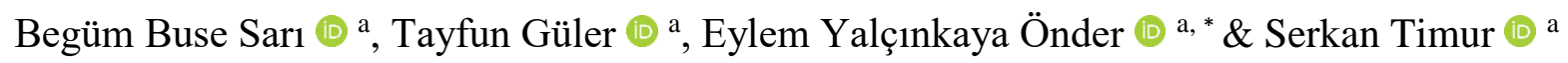 \\ a Department of Science Education, Faculty of Education, Çanakkale Onsekiz Mart University, Çanakkale, Turkey
}

\begin{abstract}
During the Covid-19 pandemic outbreak that affected the whole world, the existence and function of education informatics network gained much more importance than before. It is also important to bring teachers and students together on the same platform by providing rich educational content, especially in such a period. In the current study, secondary school teachers' opinions about EBA were determined through semi-structured interviews.

The data of the study were collected through semi-structured interviews, one of the qualitative research methods.

A case study was adopted as a research design. The study was carried out in the spring semester of the 2019-2020 academic year. A total of six teachers including one mathematics and five science teachers from various provinces and districts of Turkey. The teachers participating in the research were selected by purposeful sampling method, taking into account the criteria of using the informatics network (EBA) continuously in education during their education activities.

The data obtained from the interviews were analyzed with content analysis, coded and themes were created. Results indicated that although teachers sometimes experience technical problems, they generally stated that they found EBA contents useful for students. They thought that EBA offers students versatile features and contains content according to almost every student's learning style. In addition, teachers also mentioned the benefits of EBA in terms of reporting a lot of information such as what activities students did in EBA, which questions they solved, and the correct/incorrect rates of solved questions. Teachers also stated that there are many features that should be added to EBA. They thought that the number of simulation applications and online games on the platform should be increased. Although some of the teachers thought that the questions in EBA were useful for the students, while others thought the questions were insufficient in scope. In addition to these, teachers criticized that students' entry to EBA is limited for a certain period of time.
\end{abstract}

Keywords: Education Informatics Network, Teachers' Opinions.

\section{Özet}

Tüm dünyayı etkisi altına alan Covid-19 salgını döneminde eğitim bilişim ağının (EBA) varlığı ve işlevi eskisinden çok daha fazla önem kazanmıştır. Özellikle böyle bir dönemde zengin eğitsel içerik ortamı sağlayarak öğretmenleri ve öğrencileri aynı platformda

\footnotetext{
* Corresponding author:

Eylem Yalçınkaya Önder, Department of Science Education, Faculty of Education, Çanakkale Onsekiz Mart University, Çanakkale, Turkey. Email: eylemyk@gmail.com
} 
bir araya getirmesi de ayrıca önemlidir. Bu çalışmada ortaokul öğretmenlerinin eğitim bilişim ağı (EBA) hakkındaki görüşleri incelenmiştir.

Çalışmanın verileri nitel araştırma yöntemlerinden yarı yapılandırıımış görüşmeler aracılığıyla toplanmıştır. Araştırma deseni olarak durum çalışması benimsenmiştir. Çalışma 2019-2020 eğitim öğretim yılının bahar döneminde yürütülmüştür. Araştırmanın çalışma grubunu bir ortaokul matematik öğretmeni, beş de fen bilgisi öğretmeni olmak üzere toplamda altı öğretmen oluşturmaktadır. Araştırmaya katılan öğretmenler, eğitim-öğretim faaliyetleri sırasında eğitim bilişim ağını (EBA) sürekli kullanma kriteri dikkate alınarak amaçlı örnekleme yöntemi ile seçilmiş̧ir.

Görüşmelerden elde edilen veriler içerik analizi ile çözümlenmiş, kodlanmış ve temalar oluşturulmuştur. Çalışmanın sonuçları göstermiştir ki; öğretmenler bazen EBA'ya bağlanma gibi teknik problemler yaşasalar da genel olarak EBA içeriklerini öğrenciler için faydalı bulduklarını ifade etmişlerdir. EBA'nın öğrencilere çok yönlü özellikler sunduğunu ve hemen hemen her öğrencinin öğrenme stiline göre içerik barındırdığını belirtmişlerdir. Ek olarak, öğrencilerin EBA'da neler yaptıklarını, hangi soruları çözdükleri, çözülen soruların doğru/yanlış oranları gibi pek çok bilgiyi raporlama açısından EBA'nın faydalarından da bahsetmiş̧lerdir. Öğretmenler ayrıca simülasyon uygulamaları ve çevrimiçi oyunların sayısının artırılması gibi EBA'ya eklenmesi gereken pek çok özellik olduğunu ifade etmişlerdir. Öğretmenlerin bir kısmı EBA'daki soruların öğrenciler için yararlı olduğunu düşünürken, bazıları ise soruların kapsam olarak yetersiz olduğu fikrine sahiptirler. Bunlara ek olarak öğretmenler, öğrencilerin EBA'ya girişlerinin belirli bir süreyle sınırı olmasını da eleştirmişlerdir.

Anahtar Kelimeler: Eğitim Bilişim Ağı, Öğretmen Görüşleri.

Received: 29 September $2020 \quad$ * Accepted: 29 December $2020 \quad * \quad$ Dol: https://doi.org/10.29329/jpee.2020.282.1

\section{INTRODUCTION}

With the 21st century, technology has reached all areas of our lives and has been actively used in all sectors. In this case, not using technology in the education sector would result in raising individuals isolated from society (Saklan and Ünal, 2018). The development of technology has enabled the creation of many tools and different learning environments that can be used in education (Alabay, 2015). Thanks to the developing technology, it has become much easier to access information.

With the developing technology in Turkey, many projects are carried out in order not to fall behind the needs of the age and to use technology in education in the most efficient way. In this context, FATIH Project is one of these projects which was put into practice by the Ministry of National Education in 2012. With the FATIH project, which started the pilot implementation period in the second semester of the 2011-2012 academic year, schools were provided with smart boards, printers and cameras, and internet infrastructure. In addition, tablets were distributed to teachers and students (Kuyubaşığlu and Kılıç, 2019).

Education Informatics Network (EBA) is one of the most important elements of FATIH project. EBA was developed by the General Directorate of Innovation and Educational Technologies in order to 
provide e-content in an easy and convenient way. EBA is divided into sections such as lecture, video, course, news, book, magazine, distance education, competition (Coşkunserçe and İşçitürk, 2019). EBA is constantly kept up-to-date and enriched with file upload, announcement corner, and courses that can be adjusted for all levels. The contents in the Education Informatics Network are produced by experts in their field and enriched with the contents produced by education companies around the world. Providing free services to teachers and students, EBA is also becoming a platform that is constantly growing and constantly enriched in terms of content thanks to the sharing of teachers and students (EBA, 2018).

The contents in EBA offer different learning environments designed by considering the individual differences of the students. It helps students who have numerical, verbal, visual, auditory, individual and social learning skills with their content in different styles. In this way, EBA contributes to the training of individuals who have moved away from memorization, who inquire and question, and who can derive knowledge from knowledge (EBA, 2018). It is aimed that students learn the e-contents available in EBA by using information and communication technologies on their own, and it is aimed to provide multimedia with interactive contents. In addition, EBA is a great resource for teachers and students and a network that they can apply whenever they want (Kuyubaşığlu and Kı1ıç, 2019). The main purpose of EBA is to provide the FATIH project's principle of equal opportunity in education (EBA, 2018).

The benefits of EBA in the continuation of educational activities are indisputable. In particular, the need for such reliable systems managed by experts in the field is evident due to the Covid-19 pandemic outbreak, which surrounded the whole world and caused various disruptions in education. In literature, there are studies that clearly express the contributions of EBA to educational activities (Ünal and Hastürk, 2017; Açıkgöz, 2018; Kırıcı, Artun, Bakırcı, 2018; Yerli, 2018). Teacher opinions are the most appropriate source to learn about the effectiveness of this platform. In addition, teachers' opinions are important in order to identify deficiencies and excesses in terms of features and content on the platform and to provide feedback. Therefore, secondary school teachers' opinions about education informatics network (EBA) were investigated through semi-structured interviews.

\section{METHODOLOGY}

\section{Research Design}

Interview technique, one of the qualitative research data collection methods, was used in this study. Qualitative research is the process of presenting events or situations in their own environment in a natural way (Kafadar, 2016). According to Yıldırım and Şimşek (2016), qualitative studies are researches in which situations or events are examined realistically in their own environment by using data collection techniques such as interview, observation and document analysis. In the current study, a 
case study was adopted as a research design. Case studies are the process of revealing a certain event and situation as it is by examining it holistically (Yıldırım and Şimşek, 2016).

\section{Study Group}

This study was conducted with a total of six teachers including one mathematics and five science teachers from various provinces and districts of Turkey. These teachers constantly use education informatics network (EBA) during education and training activities. This study group was selected by the purposeful sampling. Purposeful sampling is the selection of situations that are suitable for the purpose of the study and rich in information in order to conduct an in-depth analysis (Büyüköztürk, K1lı̧-Çakmak, Akgün, Karadeniz and Demirel, 2017).

\section{Data Collection Tools}

A semi-structured interview form was used to collect data. The interview form was prepared by the researchers of the study. 20 questions in the interview form were examined by experts in the field. The interview form was rearranged in line with the suggestions made and eight questions were removed. The final version of the interview form consists of 12 open-ended questions including 3 personal information questions.

\section{Data Analysis}

Content analysis method was used to analyze the data obtained through semi-structured interviews. Content analysis is the conceptualization and interpretation of the data that overlaps and is thought to be related among the obtained data under a specified topic (Yıldırım and Şimşek, 2016). MAXQDA 2018 qualitative data analysis program was used to analyze the data obtained from the interviews in a more organized manner. The opinions of the teachers were included in the findings section. Teachers were coded as T1, T2, T3, T4, T5 and T6.

\section{Limitations of the Study}

Due to the Covid-19 pandemic outbreak, interviews with teachers were not conducted face-toface, but via zoom application. The Covid-19 pandemic caused teachers to use EBA more frequently and affected their opinions in this area.

\section{FINDINGS}

The answers of teachers to the questions regarding their opinions about EBA were collected under certain themes.

\section{Teachers' EBA Usage Frequencies and their Competencies}

Teachers were asked to what extent they use EBA in educational activities. They stated that they try to use EBA more frequently, even every day of the week, especially during the pandemic period. 
They stated that they mostly conduct synchronized lessons with students via EBA, give homework to students, and use EBA for checking student homework. Examples of teacher views on this issue are given below;

"I use EBA 7 days a week. I teach every day on weekdays and go to check the students' homework on weekends. I actively use EBA every day of the week to see which student watches which video, which student does which activities, which students solve which questions, and the correct/incorrect response rates for the solved questions." (T4)

"I use EBA constantly during the week. I use it for homework checks on the weekend. " (T6)

\section{Effects of Teaching with EBA on Teachers' Behavior}

Teachers mentioned the difficulties of providing communication in the lessons held on such a platform. They emphasized that they should gain more practice in using technology. They said that motivating students in the lessons in this educational practice is a very important and difficult task. Some of the teachers' views on the subject are as follows;

"I do not find myself very competent in handling subjects in this way. Frankly, I think it should be the real classroom environment, I miss the classroom environment where we teach face to face. I realize that the behavior I noticed misses this classroom environment. " (T1)

"In the synchronized lesson process, EBA is just a tool. During this process, I realized that we had a long way to go about technology that I would call myself a teacher who uses technology, but sometimes I find myself behind technology in some cases, and I wish I had spent more time developing myself in terms of technology and gained a little more practice. Every day a new vehicle, a new product with technological infrastructure emerges and we cannot keep up with their speed. That's why I felt the lack of this in myself during this process. I think another deficiency was a communication problem. While we were laughing and joking when it came to the classroom, everything started to be awkward here because we do not make video calls. We are completely like talking to ourselves in the room. Therefore, I think we need to improve ourselves a little bit about communication. During this process, there were situations where I felt very helpless because it is very difficult to get the attention of the students towards the lesson. There are too many distracting factors in the home environment of students, and we are constantly trying to get their attention and it is very tiring. " (T4)

"I've been mentally tired since we switched to distance education because it is very difficult to motivate students. Even if we were at school, a gesture, a loud voice, or even the slightest touch was all it takes, but now I'm struggling to be convinced that the students are listening and understanding me. At this point I feel more mentally tired. " (T5) 


\section{Problems Encountered in Using EBA}

Teachers mostly talked about technical problems. Almost all of the teachers stated that they had difficulty in logging in EBA due to the intensity of many people trying to connect/access to EBA at the same time. Teachers generally talked about the problem of freezing of the screen and kicking out of the system due to this intensity in EBA. One teacher specified that teachers' content sharing requires very long steps and the time given for the students is not enough. Some of the teachers' views on the subject are as follows;

"I did not have any problems while entering the EBA until only the first peak period when it was on the first holiday after 13 March. I can then access it with a normal speed internet connection without any problems. " (T1)

"Most of our problems are internet connectivity issues. Due to excessive clutter, we are experiencing serious problems on the internet. Our connection problems were more frequent in the first weeks, not that long after the holiday, but it was a problem for all the children to log in at the same time and connect to EBA. (T4)

"There are many steps in the process of producing and sharing the contents produced by us. In other words, we do not have trouble sharing other teachers' or EBA's own content, but when we want to create and share a material ourselves, there are many steps we have to go through. Apart from that, the time reserved for students' use is really short. For instance, I give homework to the children, they can finish the homework in just two days and they even have to leave it incomplete. $"(T 2)$

"There are children in their homes without computers and phones. We cannot reach every student, but our government is working on this issue." (T6)

\section{Advantages of EBA}

It has been clearly emphasized that EBA is rich in content. In addition to this broad content provided by EBA, teachers found its effects on different learning styles very beneficial. In distance education, it has been observed that the students report submitted by EBA to teachers are also an important part of this system. Teachers think that the videos in EBA have a very important role in terms of reinforcing the subjects by offering the students the opportunity to watch the lessons again. The high visual content of EBA increases the motivation of the students to the lesson and motivates them to learn more. The activities that cannot be done in the classroom environment during the distance education process can be easily done on the board with the simulations in EBA. Some teacher views are as follows;

"Its content is really rich, broad and most importantly, vivid in my opinion, because it is animation-based and provides students with a different motivation. I think they can focus more 
easily that way and most importantly, I think they can really learn, even if there is no teacher guidance." (T3)

"I think EBA is a savior in distance education because it is a platform where we can control all students collectively; who spent how much time at EBA, who did which activities, who has how many correct and wrong answers to questions, we can follow up all of them. In this way, we can track which student attended the activities for how long, and we can see who has completed the videos. In that respect, I find EBA useful. It is also an advantage that we can add content. " (T4)

"The biggest benefit is that I usually use the videos there to review topics. Sometimes I can easily explain things that I cannot explain by writing on the blackboard with a pen, with the help of videos in EBA. As a third benefit, it may be that the student could not understand a topic. The contents in EBA can give the teacher an idea to make the child understand that subject. I think EBA has that richness. " (T1)

"For example, I may not be able to do every experiment in the lesson when my time is not enough, but EBA can support it with simulations and experiments." (T5)

\section{Development of EBA}

The teachers emphasized that EBA is mostly a visual platform, but the number of simulations is quite low compared to such a platform according to them. They stated that augmented reality applications should be added, and the number of online games should be increased in that platform. One teacher stated that the printing of the questions in EBA should be facilitated. They stated that there should be no time limitation for students on this platform. Some of the teachers' views on this subject are given below;

"A feature that should definitely be added to EBA is that all sample questions, unit evaluation questions, and subject comprehension tests in EBA can be downloaded as a document. We took screenshots of the questions in EBA one by one, added to word document and worked on them. I would prefer that all the questions in EBA could be downloaded as a single document and easily printed. " (T1)

"I think if we have such an alternative, it would be great to upload videos and experiments as possible. I would like to have augmented reality and applications in this style. The number of online games can be increased. It can be like a puzzle. " (T5)

"It would really be nice if there could be something, we can be sure that all the students are listening to us. I wish they could concentrate on their notebooks. " (T6)

"Absolutely content. Questions and video examples exercises, games-based exercises, exercises are very rich that would attract the attention of children, there is a lot of content. I like it very 
much. One feature that needs to be highlighted is definitely the questions, unit comprehension questions, subject questions. It has very rich and high-quality questions. In other words, children should prefer these questions rather than the questions of publishing houses. And, I think this feature should be highlighted and the children should be more motivated to engage in EBA. " (T1)

"Frankly, I like the activities within the science lesson. The activities are already rich, but I think it would be more beneficial if the content of the activities is expanded and highlighted further, because we do not have the opportunity to do everything as an experiment, activities can close this gap. (T3)

\section{Face-to-face Education vs Distance Education}

Although we are in the age of technology, it is mentioned that not all students can benefit from technology-based education because it requires certain infrastructures. It was stated that not all students should be treated in the same way in synchronized lessons due to the lack of even the feeling of being in the same environment with the students in face-to-face education. Some teachers mentioned the difficulties of communicating in distance education. Some of the teachers' views on the subject are as follows;

"First of all, the student and the teacher are like parts of a whole, but in EBA, these two basic elements are separate from each other and not in the same environment. While face-to-face education is done with everyone in the classroom, distance education can only be used by students with technological tools. Communication can have negative psychological effects without our gestures. In face-to-face education, if there was a child who was more naughty than the others in the classroom, we could intervene at that moment, we could develop different methods to listen to the lessons, but unfortunately, we have to look more generally in the education we do through EBA because our time is limited. " (T2)

"Communication is much easier in face-to-face education because we can make eye contact with students and focus their attention with our gestures and body language. I think this is the biggest difference between face-to-face education and distance education. " (T6)

\section{CONCLUSION}

During the Covid-19 pandemic outbreak that affected the whole world, the existence and function of education informatics network such as EBA gained much more importance than before. It is also important to bring teachers and students together on the same platform, as it provides them with a rich educational content environment. In the current study, secondary school teachers' opinions about EBA were determined through semi-structured interviews. 
The teachers interviewed stated that they constantly use EBA in educational activities. Due to the pandemic period, synchronized lessons are done via EBA and homework is given on this platform, increasing their frequency of using EBA. Teachers also checked the students' homework through this platform. Although the interviewed teachers found the lessons conducted on this platform useful, they stated that teaching through EBA was a different situation and they preferred teaching in a real classroom environment to the current situation. The reason for this situation stems from the fact that teachers are not used to lecturing on such practices and they adopt teaching in the classroom environment.

Teachers stated that while accessing this educational platform, they sometimes experience problems due to the fact that many teachers and students try to connect to EBA at the same time. In this period, it is thought that such technical problems have arisen due to the lack of server and infrastructure with students and teachers frequently logging into EBA. Likewise, Tüysüz and Çümen (2016) stated that some students and teachers experienced some technical problems such as connecting to the server or connection error due to the frequent access to EBA. In addition, interviewer teachers emphasized that although many individuals have increased access to communication tools, all students have not equal opportunities in this sense.

Teachers emphasized that EBA is very useful for students. They thought that EBA offers students versatile features and contains content according to almost every student's learning style. In addition, teachers also mentioned the benefits of EBA in terms of reporting a lot of information such as what activities students did in EBA, which questions they solved, and the correct/incorrect rates of solved questions. Similarly, Kuyubaşığlu and Kılıç (2019) emphasized that EBA has an effect on teacher motivation and that EBA addresses students with different learning styles. Most importantly, they also found out that EBA is a new tool for teachers and lessons are more enjoyable with EBA. On the other hand, while some of the students found EBA useful, some of them stated that they found it insufficient within the scope of mathematics lesson. Some of the students stated that they had difficulty using the mathematics course content in EBA, the contents of the mathematics course were not useful and the examples in the course content were few (Durmuşçelebi and Temircan, 2017)

Teachers also stated that there are many features that should be added to EBA. They thought that the number of simulation applications and online games on the platform should be increased. Although some of the teachers thought that the questions in EBA were useful for the students, while others thought the questions were insufficient in scope. In addition to these, teachers criticized that students' entry to EBA is limited for a certain period of time. Similar to the results of the current study, Timur, Y1lmaz and İsseven (2017) stated that the scope of content in EBA should be expanded and the number of questions should be increased, and the content of the course should be enriched by using the animations and interactive videos available in EBA in each course. Saklan and Ünal (2019) stated that although teachers interviewed about the EBA found that the EBA platform is valuable and promising in general, 
they criticized the qualities of some materials used in science teaching in EBA were not at the expected level. Furthermore, science teachers found the scope of some course content limited and claimed that sometimes they had problems in finding course content appropriate to students' grade levels.

Although the teachers generally found the synchronized lessons on EBA useful, they stated that they preferred face-to-face education to distance education. Teachers stated that not being able to be with their students when they needed them during the distance education period, and not being able to even provide this when they even needed any eye contact made them feel helpless. It was also noted that the main reason for the problems experienced in distance education is that both teachers and students do not have experience in distance education and are not prepared for distance education.

\section{Recommendations}

Based on the results of this study, the following suggestions are listed;

Considering the technical problems encountered in connecting to EBA and using EBA, the web infrastructure should be improved.

The number of questions in the EBA should be increased and the questions should be classified according to their difficulty.

Videos prepared for lecture or lecture review should be organized in a more motivating way for students and the number of videos should be increased depending on the variety of samples.

The time allocated for students to use EBA was not found sufficient, the time limitation should be lifted.

The number of simulations, events and digital games within EBA should be increased.

Teachers should be given information or training on this and similar platforms.

\section{REFERENCES}

Alabay, A. (2015). Ortaöğretim öğretmenlerinin ve öğrencilerinin EBA kullanımına ilişkin görüşleri üzerine bir araştırma. Unpublished master's thesis, İstanbul Aydın Üniversitesi, İstanbul.

Açıkgöz, G. (2018). Eğitim bilişim ağı (EBA) destekli matematik öğretiminin 7. Sınıf öğrencilerinin akademik başarısına etkisi (The effect of educational informatics network (EBA) assisted maths teaching on academic achievement of seventh grade students). Unpublished master's thesis, Kastamonu Üniversitesi, Kastamonu.

Büyüköztürk, Ş., Kılıç-Çakmak, E., Akgün, Ö., Karadeniz, Ş., \& Demirel, F. (2017). Eğitimde bilimsel araştırma yöntemleri (26. Baskı). Pegem Akademi Yayınları, Ankara.

Coşkunserçe, O., \& İşçitürk, G. B. (2019). Eğitim bilişim ağı (EBA) platformu hakkında öğrencilerin farkındalığının artırılmasına yönelik bir durum çalışması. Eğitimde Nitel Araştırmalar Dergisi, 7(1), 260-276. 
Durmuşçelebi, M., \& Temircan, S. (2017). MEB (Eğitim Bilişim Ağı) EBA'daki eğitim materyallerinin öğrenci görüşlerine göre değerlendirilmesi. OPUS Uluslararası Toplum Araştırmaları Dergisi, 7(13), 632-652.

Kırı1, M. G., Artun, H., \& Bakırcı, H. (2018). Eğitim bilişim ağı destekli eğitimin kuvvetin ölçülmesi ve sürtünme kavramlarının öğrenilmesine etkisi. Turkish Studies, 13(3), 23-38.

Kuyubaşığlu, R. M., \& Kılıç, F. (2019). Ortaokul öğretmenlerinin görüşlerine göre EBA (Eğitimde Bilişim A $\breve{1}$ ) kullanım düzeylerinin incelenmesi. Journal of Advanced Education Studies, 1(1), 32-52.

MEB (2018). FATIH Project. Retrieved from http://fatihprojesi.meb.gov.tr/about.html

Saklan, H., \& Ünal, C. (2018). Teknoloji dostu fen bilimleri öğretmenlerinin eğitim bilişim ağı (EBA) hakkındaki görüşleri. Necatibey Eğitim Fakültesi Elektronik Fen ve Matematik Eğitimi Dergisi, 12(1), 493-526.

Saklan, H., \& Ünal, C. (2019). Dijital eğitim platformları arasında EBA'nın yeri ile ilgili fen bilimleri öğretmenlerinin görüşleri. Ondokuz Mayıs Üniversitesi Eğitim Fakültesi Dergisi, 38(1), 19-34.

Timur, B., Yılmaz, Ş., \& İşseven, A. (2017). Ortaokul öğrencilerinin eğitim bilişim ağı (EBA) sistemini kullanmalarına yönelik görüşleri [Secondary school students' opinion for using the system of education information network (EBA)]. Asian Journal of Instruction, 5(1), 44-54.

Tüysüz, C., \& Çümen, V. (2016). Opinions of secondary school students about EBA course website. Uşak Üniversitesi Sosyal Bilimler Dergisi, 9(3), 277-296.

Ünal, B. B., \& Hastürk, G. (2018). Fen bilimleri dersinde eğitim bilişim ağı (EBA) kullanımının ortaokul öğrencilerinin akademik başarılarına etkisi. Uluslararası Beşeri Bilimler ve Eğitim Dergisi, 4(7), 327 342.

Yerli, M. S. (2018). Sosyal bilgiler öğretiminde eğitim bilişim ağı (EBA) uygulamasının öğrencilerin akademik başarısına etkisi (The effect of education informatics network (EBA) application onstudents academic successin teaching social studies). Unpublished master's thesis, Adiyaman Üniversitesi, Adiyaman.

Şimşek, H., \& Yıldırım, A. (2016). Sosyal Bilimlerde Nitel Araştırma Yöntemleri [Qualitative research methods in social sciences]. Ankara: Seçkin Publishing. 